\title{
Research on double-faced jacquard fabric with compound full-backed structure of three wefts
}

DOI: $10.35530 / 1 T .072 .05 .1725$

\section{ABSTRACT - REZUMAT}

\section{Research on double-faced jacquard fabric with compound full-backed structure of three wefts}

Weft-backed structures with compound weft colours can express the mixed colour effect. However, this structure is not suitable for jacquard fabrics with a double-faced shading effect in the traditional single layer design mode. Taking twenty-thread sateen with a step number (S) of 7 as an example, this paper investigates a design method for compound full-backed structure with three shaded-weave databases (SWDs) by selecting the primary weaves (PWs), designing the compound full-backed technical points and establishing the compound structure database with three SWDs. With this design method, a double-faced shading effect in combination with non-backed and full-backed effects on different sides of the jacquard fabric at the same position is generated. The fabric colour card was produced with three SWDs and three sets of different coloured wefts, and their colour values were measured, followed by an analysis of the compound structures on the reverse side, lightness, colour purity and colour difference $\left(\Delta E^{*}{ }_{a b}\right)$ of the specimens. The results showed that the three covering effects on the reverse side, partly covered, critical position and totally covered, could be adjusted by controlling the step number and the transition direction of PW-C. For the specimens on the edges of the fabric colour card, their lightness and colour purity values showed a uniform transition effect along with the shading process; their colour differences ranged from 1.23 to 3.69, both in the range of 2-5, and showed a trace or slight colour difference between two adjacent fabric specimens, indicating that the colour shading effect with the three SWDs is stable.

Keywords: weft-backed structure, compound full-backed structure, double-faced, shading effect, colour rendering law

\section{Studiu privind țesătura jacquard cu două fețe cu structură compusă - semitriplă de bătătură}

Structurile semiduble de bătătură, în combinatie cu bătături colorate pot exprima efectul de amestec de culoare. Cu toate acestea, această structură nu este adecvată pentru țesăturile jacquard cu efect de umbrire cu față dublă, proiectată tradițional, cu un singur strat. Luând ca exemplu un raport de douăzeci de fire cu legatură atlas cu un salt (S) de 7, această lucrare investighează o metodă de proiectare pentru structura compusă, semitriplă de bătătură cu trei baze de date cu legături cu efect de umbrire (SWD), prin selectarea legăturilor de bază (PW), proiectând puncte tehnice de legare completă a sistemelor de fire și stabilirea bazei de date a structurii compuse cu trei SWD-uri. Cu această metodă de proiectare, se generează un efect de umbrire cu două fețe în combinație cu efecte de nelegare și legare completă a sistemelor de fire, pe diferite părți ale țesăturii jacquard, în aceeași poziție. Grila de culori a țesăturii a fost produsă cu trei SWD-uri și trei seturi de bătături diferit colorate, iar valorile tonurilor de culoare au fost măsurate, fiind urmată de o analiză a structurilor compuse, pe partea din spate, luminozitate, puritatea culorii și diferență de culoare $\left(\triangle E^{*} a b\right)$ a probelor. Rezultatele au arătat că cele trei efecte de acoperire pe partea din spate, parțial acoperită, poziție critică și total acoperită, ar putea fi ajustate prin controlul saltului și direcția de trecere/legare a PW-C. Pentru probele de pe marginile grilei de culoare ale țesăturii, valorile lor de luminozitate și puritate a culorii au arătat un efect de trecere uniform, împreună cu procesul de umbrire; diferențele lor de culoare au variat între 1,23-3,69, ambele în intervalul 2-5 și au arătat o urmă sau o ușoară diferență de culoare între două probe de țesături adiacente, indicând faptul că efectul de umbrire a culorii cu cele trei SWD-uri este stabil.

Cuvinte-cheie: structură semidublă de bătătură, structură compusă cu legare completă a sistemelor de fire, două fețe, efect de umbrire, lege de redare a culorilor

\section{INTRODUCTION}

Double-faced jacquard fabric is a special woven fabric that can express the patterning and colour effects on both the face and reverse sides of the fabric. Among the structures woven by warp and weft yarns, five types of structures can form a double-faced effect [1-3], which are single-layer structure woven by one set of warps and one set of wefts, weft-backed structure woven by one set of warps and two or more sets of wefts, warp-backed structure woven by one set of wefts and two or more sets of warps, doublelayer structure woven by two sets of warps and wefts, and multi-layer structure woven by multiple sets of warps and wefts, respectively.

Weft-backed jacquard fabric, a typical product of the Chinese traditional woven fabric industry, has an exquisite patterning woven effect with the weftbacked structure that is composed of one set of warps and two or more sets of colour wefts [4]. The main feature of the weft-backed structure is that the 
weft yarns are arranged in an overlapping manner in the compound structure combined by several single weaves; thus, the patterning and colour effects are textured by one or several sets of wefts, and the remaining sets of wefts are totally covered. The richness of the woven colours is realized only by the exchange of the surface and inner wefts; thus, the more the weft groups, the richer the woven pattern effect [5], but correspondingly, the more difficult

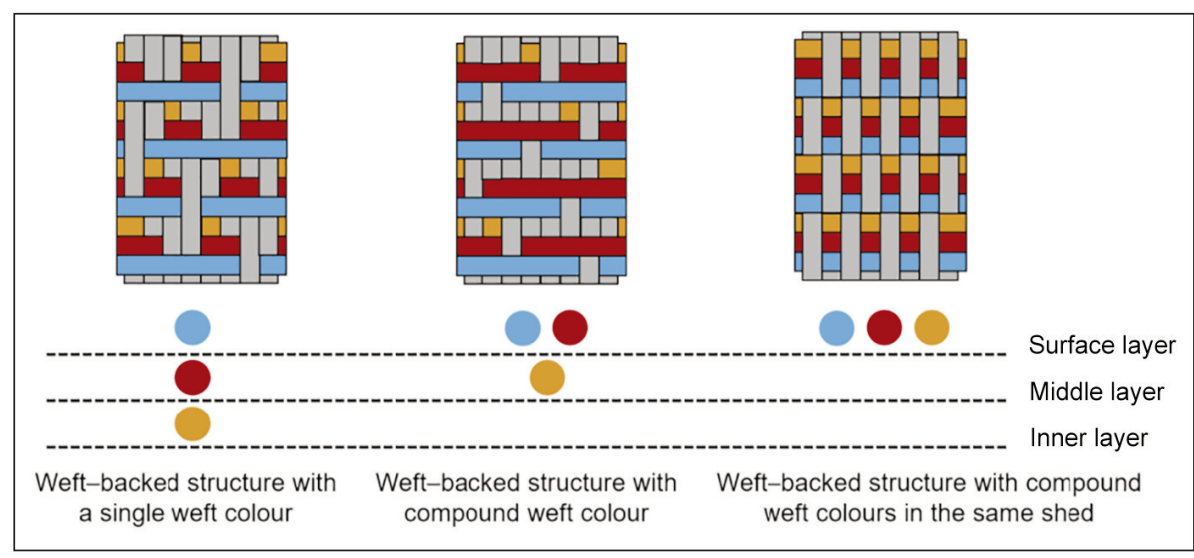

Fig. 1. Three weft-backed structures with three wefts (the arrangement ratio is $1: 1: 1$ in the weft direction)

the design process. Moreover, this structure has only one set of warps, and it is necessary to consider both sides when designing fabrics with a double-faced effect. Therefore, weft-backed jacquard fabric mostly has a single-faced effect, which leads to the underutilization of the colour information of the woven yarns [6]. The shaded-weave structure has been used as an optimum solution for structural barriers to colour expression [7], which can achieve a doublefaced shading effect. By increasing or decreasing the interlacing points by a certain rule, a series of waves shading from weft face weave to warp face weave or from warp face weave to weft face weave, are gathered in a shaded weave database (SWD) [8, 9]. By combining several SWDs, a compound structure is created with high reliability to realize a smooth colour shading effect.

In general, the patterning effect of weft-backed fabric is formed by long weft floats. To make the pattern more visible against the ground, its ground weave is normally woven by a plain weave or regular satin weave with a coloured warp. The ground structure of weft-backed fabric has three colour effects-single weft colour, compound weft colours, and compound weft colours in the same shed [4, 10, 11]:

- In a weft-backed structure with a single weft colour, a weft with more weft floats serves as the fabric surface, whereas the wefts with fewer weft floats are totally covered and have no influence on the colour effect of the surface wefts. Thus, the colour information of only one group of wefts is shown on the surface layer of the fabric (figure 1).

- In a weft-backed structure with compound weft colours, two or more sets of coloured wefts are interwoven with one set of warp yarns, forming the fabric surface to cover the remaining wefts that are backed on the reverse side. Thus, a mixed colour effect with two or more coloured wefts is generated on the surface layer (figure 1).

- In a weft-backed structure with compound weft colours in the same shed, the surface weave is woven by two or more wefts in the same shed; in other words, the weaves of the compound structure are precisely the same. Therefore, any weft yarns may be visible on the surface layer (figure 1), and a shot-effect can be expressed on the fabric surface. However, the coverage degree of the woven yarns and the colour effect are difficult to determine.

Among the three compound structures, the weftbacked structure with compound weft colours has the most abundant changes. When applying shaded weaves on this structure with three wefts, a compound shading effect with two different colour wefts on one side and a single colour shading effect with another weft on the other side can be realized on the same position of the double-faced jacquard fabric; at the same time, the structural features of the weftbacked structure are retained. Thus, based on the weft-backed structure with compound weft colours, a novel compound structure with SWDs is proposed with details for the compound structure design, colour rending characteristics and coverage relationship of the three wefts.

\section{DESIGN OF A COMPOUND FULL-BACKED STRUCTURE WITH THREE WEFTS}

According to the compound structure design principle, interwoven yarns arranged in the same direction have three relationships-full-backed, non-backed and partial-backed $[12,13]$ (figure 2), referring to the "backed" degree between the yarns in the same position and the same side of a fabric:

- In a full-backed structure, the weft yarns overlap each other and the surface wefts cover the inner wefts totally. Full-backed technical points have to be set up to ensure the effectiveness of single colour shading effect with the full-backed structure [14]. As for the full-backed structure with doublefaced shading effect, the surface weave and the inner weave are changed at the same time along with the colour shading process. Thus, it is not need to design full-backed technical points.

- In the non-backed structure, all wefts are visible on the surface layer, and all of them are served as the fabric surface. There is no overlapping effect between the juxtaposed wefts. In the colour shading design process, full-colour points are the key to prevent the wefts from overlapping [12]. 


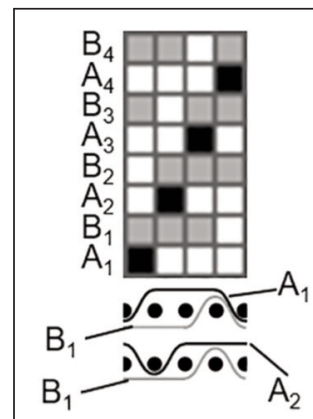

Full-backed structure

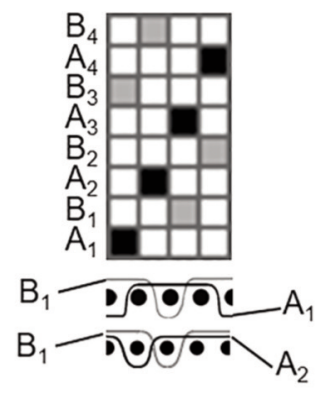

Non-backed structure

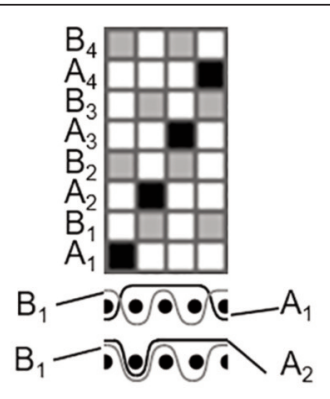

Half-backed structure

Fig. 2. Three "backed" structures

with a single colour effect and the juxtaposed wefts with a no-covering colour effect. Any one of the two juxtaposed wefts can cover one end or two ends of the adjacent covered wefts; in other words, the two wefts share at least one warp interlacing point.

Given the above design idea, the two juxtaposed wefts have an opposite configuration to satisfy the requirement of a no-covering colour effect (figure 4); what is more, some kinds of technical

- In a partial-backed structure, the effects of fullbacked and non-backed exist simultaneously. Halfbacked structure produced on the basis of a partialbacked structure is characterized in that half of the wefts are covered by its adjacent wefts [15], and half-backed points are designed to produce the half-backed effect.

The structure based on the weft-backed structure with compound weft colours, named a "compound full-backed structure" is created by the combination of three or more groups of SWDs that are derived from the primary weaves (PWs) in a way that increases or decreases the interlacing points [13]. A basic weave (BW) is a weave of a SWD. With this structure, two or more sets of different coloured wefts shading on the surface layer can completely cover the other weft yarns (a group or more groups). When the covered weft yarns are shading on the reverse side of the fabric at the same time, the compound fullbacked structure with a double-faced shading effect will be created.

\section{Design principle}

The design idea of a compound full-backed structure with three wefts is that the two sets of colour wefts (their corresponding weaves are PW-A and PW-B) are juxtaposed with each other and totally cover the remaining set of wefts (the corresponding weave is PW-C), meanwhile, the two juxtaposing wefts are shading on one side and the remaining wefts are shading on the other side (figure 3). Thus, there is a "covering" relationship between the covered wefts

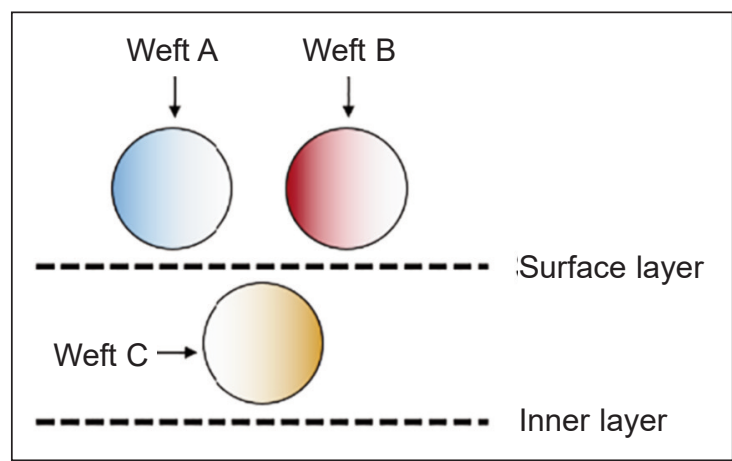

Fig. 3. Structural model of the three wefts compound full-backed points are necessary for the PWs to prevent the overlapping of the juxtaposed wefts. On the design process of the SWDs based on the PWs, the process of increasing or decreasing the interlacing points to control the float length, thereby making the most use of the colour information of the woven yarns.

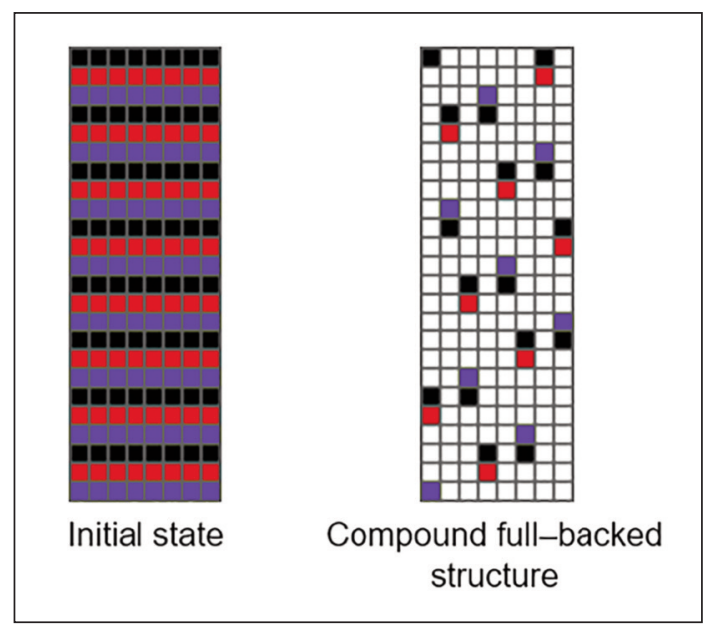

Fig. 4. Compound structure with three wefts (the arrangement ratio is 1:1:1 in the weft direction)

\section{Design method}

Selection of $P W s$

PW-A, PW-B and PW-C are the three PWs of the compound full-backed structure with three wefts. As mentioned above in the design principle, the combination of PW-A and PW-B should cover PW-C in the compound structure; therefore, the design method of $\mathrm{PW}-\mathrm{C}$ is moving the warp points of PW-A one weft down along the weft direction, and then superimpose the warp points on PW-B (figure 5). Clearly, the number of the warp points of $\mathrm{PW}-\mathrm{C}$ is larger than that of PW-A and PW-B.

The selection of the three PWs for the SWDs mainly depends on three design methods:

- Separating the odd and even wefts of a regular sateen weave. A regular sateen weave is an ideal choice for a PW among the three elementary weaves (plain weave, twill weave and satin weave) because of its uniform distribution of interlacing 


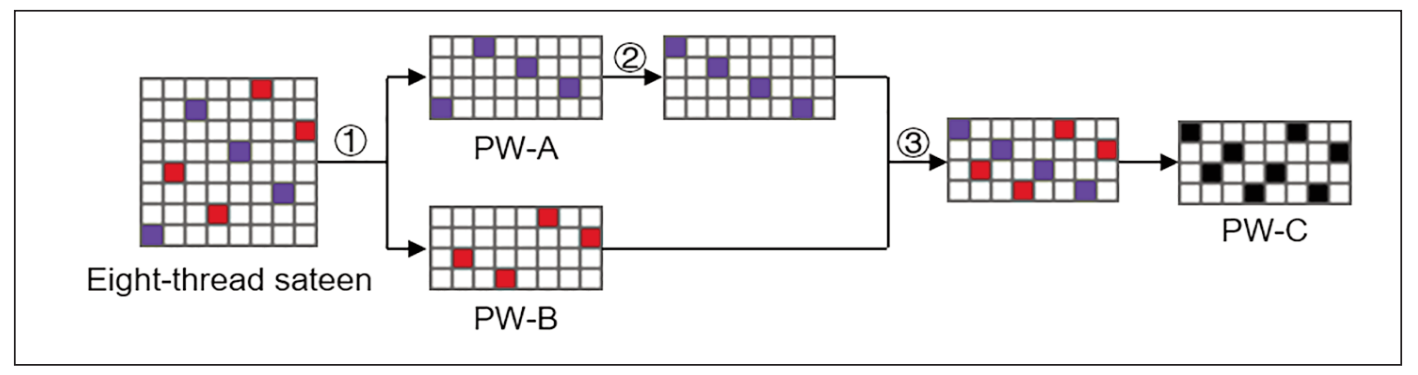

Fig. 5. Separation of the even and odd wefts of a sateen weave: 1 - the process of the separation of even and odd wefts; 2 - the process of moving PW-A one weft down along the weft direction; 3 - the process of superposing the interlacing points

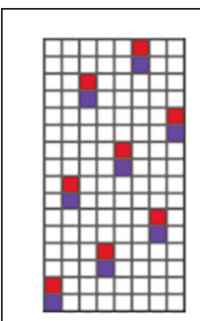

$(1,1)$

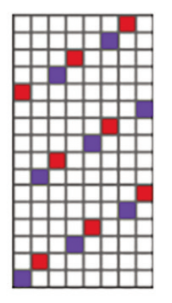

$(1,2)$

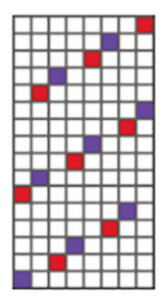

$(1,3)$

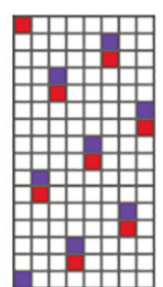

$(1,4)$

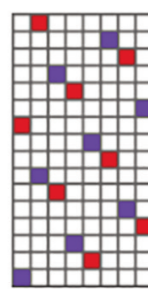

$(1,5)$

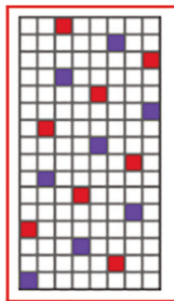

$(1,6)$

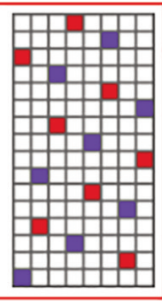

$(1,7)$

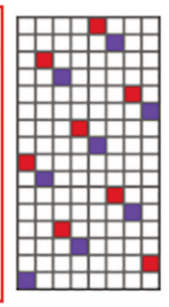

$(1,8)$

Fig. 6. Displacement of the starting points of PWs

points and its large expansibility with a high weave repeat (between 5 and 48) [16]. These advantages of a sateen weave can optimize the colour effects of the fabric surface because there are no apparent slanting lines to disturb the colour mixing effects.

- Shifting the starting points of PWs. PW-B is designed by the displacement of the starting point of PW-A in a point-by-point way; therefore, PW-A and $P W-B$ have the same weave repeat and step number but with different starting points. As shown in figure 6, the same two sets of eight-thread sateen with the starting point of $(1,1)$ were arranged with the combination method of 1-and-1 along the weft direction. One group remained unchanged, and the other group was shifted to the right point by point. This process generated eight combination effects, in which the starting points of $(1,6)$ and $(1,7)$ (the compound structures in the red frames) had an optimal uniform distribution of interlacing points. With this method, the starting point of PW-A was $(1,1)$ and that of PW-B could be $(1,6)$ or $(1,7)$.

- Using the formula to calculate the starting position of PW-B. PW-A with the parameters of weave repeat $(R)$, starting point position $\left(N_{1 A}\right)$ and step number $(S)$ is fixed; the starting point position of PW-B $\left(N_{1 B}\right)$ is calculated with equation 1 or 2 to make the distance between the interlacing points on any weft with its adjacent wefts as equal as possible. In figure 7,D1 and D2 are the distance of three adjacent warp points, the closer D1 and D2 are, the more uniform the interlacing points are distributed. In this study, taking twenty-thread sateen as the PW, the starting point of PW-A was $(1,1)$, and that of PW-B was $(1,4)$ with the formula method; after this, PW-C was designed based on PW-A and PW-B (figure 8).

$$
\begin{gathered}
N_{1 B}=\frac{R-N_{2 A}-1}{2}+N_{2 A}+1=\frac{R+S}{2}+1 \quad(S<R \\
N_{1 B}=\frac{N_{2 A}-N_{1 A}-2}{2}+2=\frac{S+2}{2}(S>R / 2)
\end{gathered}
$$

where $N_{1 A}=1, N_{2 A}=N_{1 A}+S ; N_{1 A}$ and $N_{1 B}$ are the starting positions of PW-A and PW-B, respectively; $N_{2 A}$ is the position of the second warp point of PW-B; $R$ is the number of weave repeats; and $S$ is the step number. The digit after the decimal point can be discarded or rounded off if the fraction is not an integer according to the length of $D_{1}$ and $D_{2}$.

Design of the compound full-backed technical points For the PWs, the compound full-backed point is the key factor in the establishment of a compound fullbacked structure, as follows: the technical points of

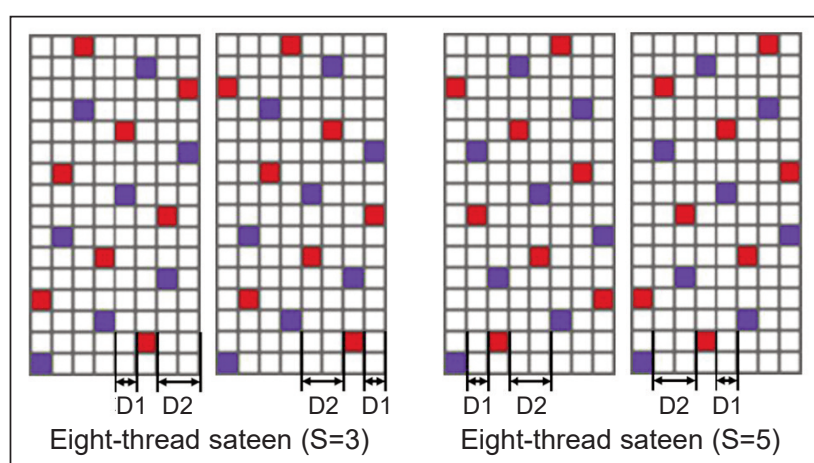

Fig. 7. Starting points of PWs 


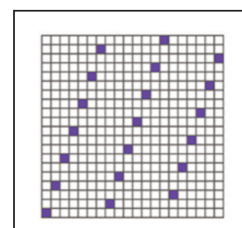

PW-A

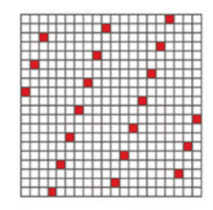

Compound fullbacked points

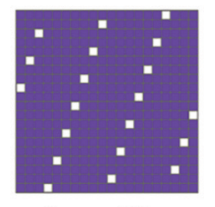

Area of the increasing points

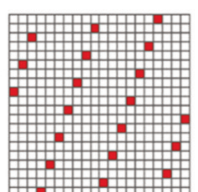

PW-B

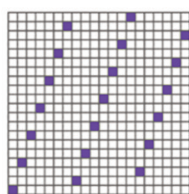

Compound fullbacked points

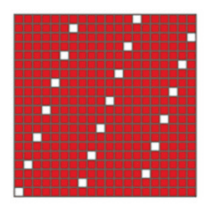

Area of the increasing points

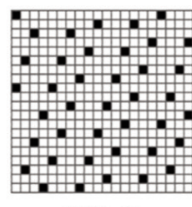

$\mathrm{PW}-\mathrm{C}$

Fig. 8. PWs and compound full-backed technical points

PW-A are to reverse the interlacing points of PW-B; similarly, that of PW-B are to reverse the interlacing points of PW-A. $J$ is the number of the compound fullbacked points of a weft, and $J=1$ here.

\section{Design of SWDs}

An SWD contains information on the design process of the derived weaves based on the PWs. In addition to the PW, two other key design factors are the increasing number at a time (coded as $N$ ) and the transition direction of the interlacing points, which separately determine the capacity and the structural balance of an SWD. The capacity of an SWD is maximal when $N=1$; thus, the variation between the shaded weaves is minimal; when $N=R$, the capacity of an SWD is minimal, and the variation between the shaded weaves is maximal [16]. Because the patterning and colour effects of the weft-backed jacquard fabric are woven by weft floats, continuous weft floats can make the woven effect more delicate; thus, the horizontal transition, in which the interlacing points are reinforced continuously in the weft direction [8], is adopted in this study to ensure the effectiveness of a compound full-backed structure. After the basic parameters are confined, three SWDs based on the above three PWs $(R=20)$ were designed by increasing the warp interlacing points $(N=R)$ in the coloured area of figure 8. Meanwhile, the compound full-backed points must be skipped in the increasing process for PW-A and PW-B. Figure 9 is the minimal SWD that is named by the number of warp points of the PWs.

To ensure the "backing" effect of the combination process of the three SWDs, two demands should be met: the arrangement ratio of the three weft yarns

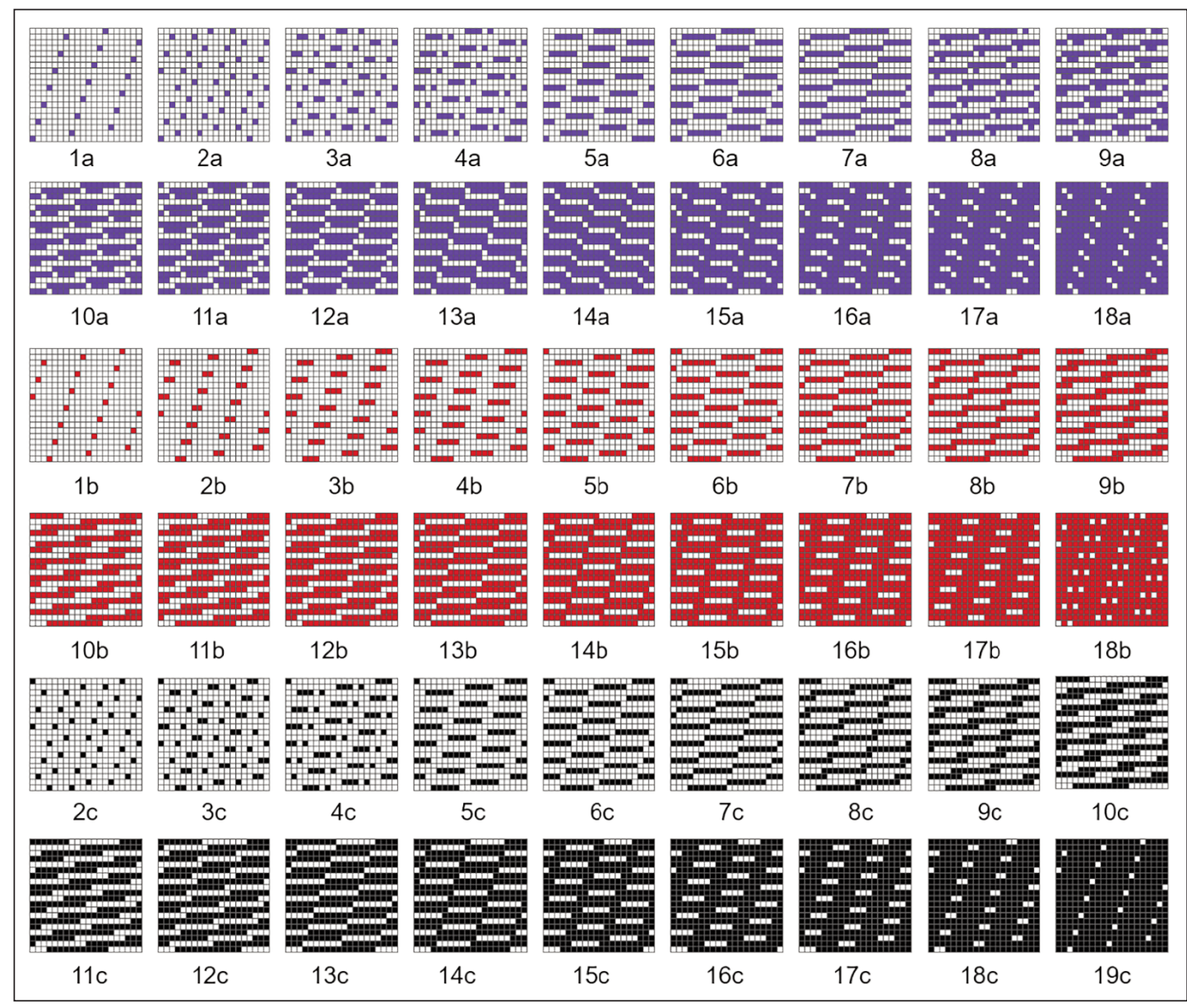

Fig. 9. Three minimal SWDs 
should be 1:1:1, and the weft float length of PW-C should be shorter than that of PW-A and PW-B (i.e., the warp points of $\mathrm{PW}-\mathrm{C}$ are more than those of PW-A and PW-B). Based on these foundations, the database of the compound full-backed structure has three combinations: i) one set of SWD is shading from weft-faced weave to warp-faced weave while the other two sets are kept unchanged; ii) two sets of SWDs are shading and the rest set is kept unchanged; iii) all three SWDs are changed simultaneously. The capacity of the compound full-backed structure database will be as shown below:

$$
\Sigma\left[(n-M+1)(M-1)+\sum(n-M+1)\right]
$$

where $n$ is the number of BW-A or BW-B, $n=18$ here; $M=1,2,3, \ldots, n$. So the capacity is 2109 .

\section{EXPERIMENTATION AND DISCUSSION}

\section{Weaving of fabric colour card}

Taking the simultaneous shading effect of the three wefts as an example, the initial position of the compound full-backed structure database is $1 a-1 b-2 c$ (the combination of three BWs), and the corresponding warp points are $(1,1,2)$. According to the aforementioned analysis, only the combination of $1 \mathrm{a}(\mathrm{BW}$ of SWD-A), 1b (BW of SWD-B) and 2c (BW of SWD-C) is effective when the PW-B is unchanged, and the colour level is 1 . Similarly, the compound structure has 2 colour levels $(1 a-1 b-3 c$ and $2 a-2 b-3 c)$ when the number of warp points of PW-C is $3(3 c)$. The remaining points can be determined in the same manner. Equation 4 is the capacity of the compound full-backed structure database with the three SWDs that changed simultaneously.

$$
1+2+3+\cdots+(R-J-1)
$$

According to equation 4 , the capacity of the three SWDs that changed simultaneously is 171 .

Meanwhile, its fabric colour card was produced and the weaving specifications were listed in table 1. Red and blue weft yarns were woven on the face side, and yellow weft yarns were woven on the reverse side. Figure 10 shows the expanded effect of the fabric colour card; the lines with arrows are the shading direction (dark to light) of the specimens.

Table 1

\begin{tabular}{|c|c|c|}
\hline \multicolumn{3}{|c|}{ WEAVING SPECIFICATIONS } \\
\hline Parameters & Warp & Weft \\
\hline Fineness (D) & 50 & 70 \\
\hline Density (ends/cm) & 114 & 105 \\
\hline Colour & white & $\begin{array}{c}\text { red (weft A) } \\
\text { blue (weft B) } \\
\text { yellow (weft C) }\end{array}$ \\
\hline Material & $100 \%$ polyester & $100 \%$ polyester \\
\hline Weave & three SWDs of 20-thread sateen \\
\hline Specimens size (cm) & \multicolumn{2}{|c|}{$3.5 \times 3.5$} \\
\hline Specimens quantity & \multicolumn{2}{|c|}{$171 \times 2=342$} \\
\hline
\end{tabular}

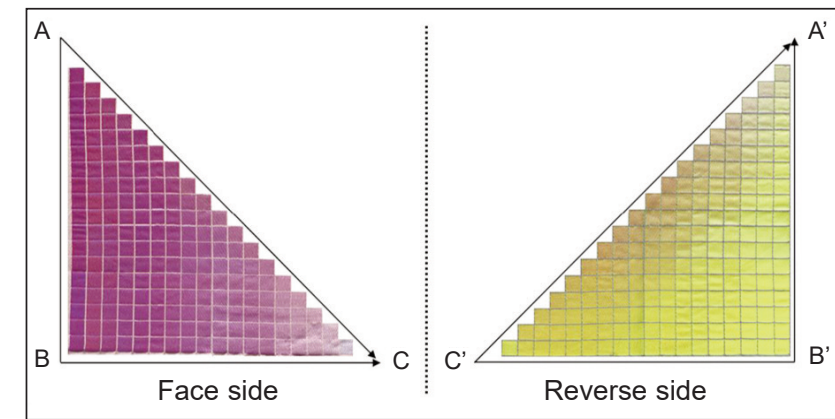

Fig. 10. Fabric colour card with three SWDs

\section{Analysis of the compound full-backed structure}

The colour card has the following characteristics through visual observation.

- Along the vertical direction, the surface waves in the same column are the same, and the backing weaves with one SWD (SWD-C) are transitioned from the weft-faced weave to the warp-faced weave with the colour shading from light to dark.

- Along the horizontal direction, the backing weaves are the same in the same line, and the surface waves with two SWDs (SWD-A and SWD-B) are transitioned from the weft-faced weave to the warpfaced weave with the colour shading from dark to light.

- Along the diagonal direction with three SWDs (SWD-A, SWD-B and SWD-C), the surface weaves are transitioned from the weft-faced weave to the warp-faced weave, and the backing weaves are transitioned from the warp-faced weave to the weftfaced weave; correspondingly, the colour of the face side shading changes from dark to light and that of the reverse side shading changes from light to dark.

- The specimens on the reverse side of the colour card are the interlacing of white warps not only with yellow wefts but also with red and blue wefts, exhibiting a complicated colour effect.

There are three covering effects between the three coloured wefts on the reverse side, namely, partly covered, critical position and totally covered (figure 11). In a partly covered effect, the yellow wefts cover only part of the red and blue wefts simultaneously; thus, the three coloured wefts are visible on the reverse side at the same time. In the critical position, the red and blue wefts begin to become visible on the surface layer of the reverse side so that the yellow wefts cannot cover the red and blue wefts simultaneously. In a totally covered effect, the yellow wefts completely cover the red and blue wefts at the same time and serve as the fabric surface of the reverse side. Figure 12 shows the statistics of the coverage degree on the reverse side of the colour card.

Viewed from the reverse side of the colour card, the three abovementioned coverage effects are closely related to the float length of the coloured weft yarns. When the weft floats of two adjacent yellow wefts $\left(Y_{1}\right.$ and $Y_{2}$ ) are not overlapped (figure 13), according to 


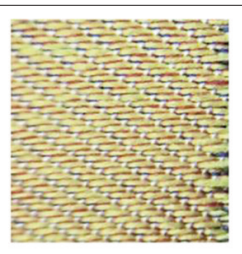

Partly covered effect

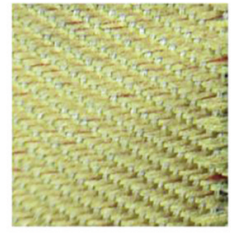

Critical position

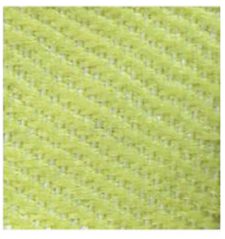

Totally covered effect
Fig. 11. Three coverage effects on the reverse side of the colour card

the design principle of the weft-backed structure, the yellow weft can separately cover either the adjacent blue weft $(B)$ or the red weft $(R)$, but because the arrangement ratio of the three wefts is $1: 1: 1$ and the specifications are the same, the yellow weft cannot completely cover the blue and red wefts that are juxtaposed in the compound structure at the same time. Therefore, the yellow wefts can cover only parts of the adjacent blue and red wefts at once. The critical position is the transition position between the partly covered effect and the totally covered effect. When the weft floats of two adjacent yellow wefts have one weft overlapping point, as shown in figure $13, Y_{1}$ can cross $B_{2}$ under the action of the beating force and then cover $R_{2}$, which can also be covered by $Y_{2}$; to this end, the weft points of $R_{2}$ can be covered by $Y_{1}$ and $Y_{2}$ at the same time. However, $W_{11}$, which is in the warp bundles of $W_{4}-W_{11}$ (gathered together by the weft floats of $Y_{1}$ ) and $W_{11}-W_{18}$ (gathered together by the weft floats of $Y_{2}$ ) at the same time, will be pulled simultaneously into their respective warp bundles under the action of the tension of the weft floats; in this scenario, the red weft point on $W_{11}$ is not completely covered and is partially exposed. When the overlapping weft points of two adjacent yellow wefts are more than the weft points of the red wefts, a total-

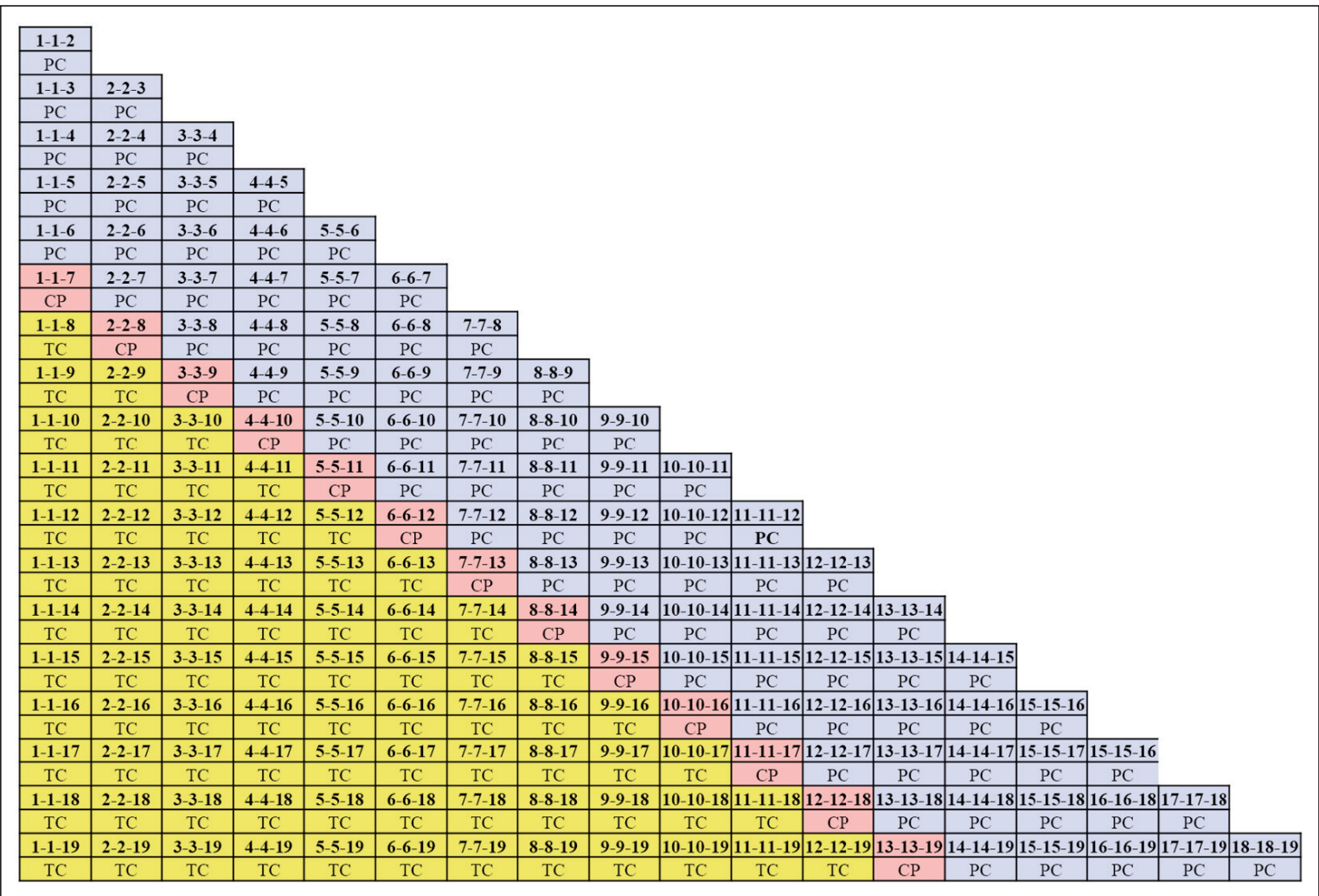

Fig. 12. Coverage degree on the reverse side of the colour card: Blue - PC-Partly Covered; Pink - CP-Critical Position; Yellow - TC-Totally Covered

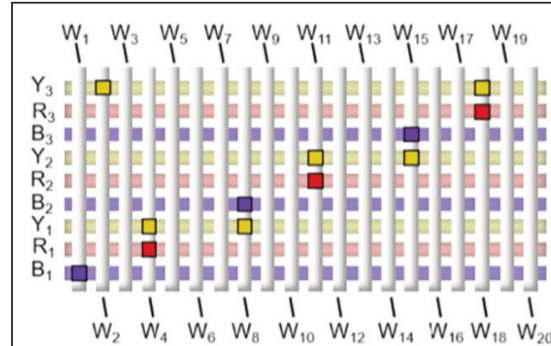

$1 a-1 b-2 c$

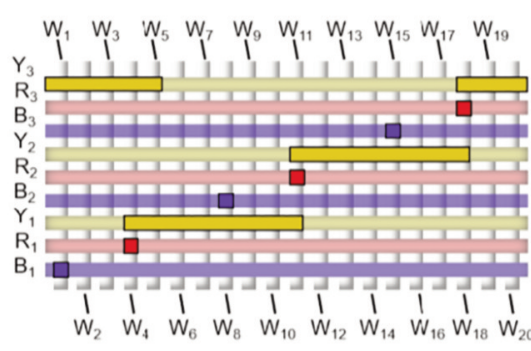

$1 a-1 b-8 c$

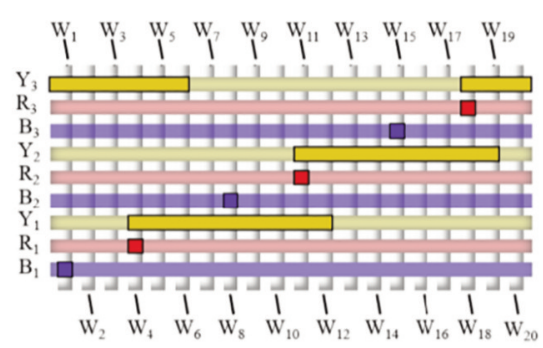

$1 a-1 b-9 c$

Fig. 13. The reverse side of the compound full-backed structures 


\begin{tabular}{|c|c|c|c|c|c|c|c|}
\hline \multicolumn{8}{|c|}{ OVERLAPPING ANALYSIS OF PW-C (PART OF THE COMPOUND STRUCTURE) } \\
\hline $\begin{array}{c}\text { Step } \\
\text { number }\end{array}$ & $\begin{array}{l}\text { Interlacing } \\
\text { direction }\end{array}$ & & terlacing number & $\begin{array}{c}\text { Step } \\
\text { number }\end{array}$ & $\begin{array}{l}\text { Interlacing } \\
\text { direction }\end{array}$ & & terlacing number \\
\hline 3 & \multirow{6}{*}{ right } & 4 & 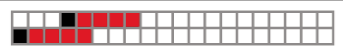 & 3 & \multirow{6}{*}{ left } & 18 & 10 \\
\hline 7 & & 8 & 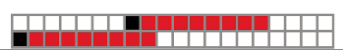 & 7 & & 14 & 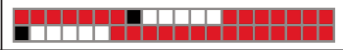 \\
\hline 9 & & 10 & 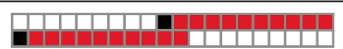 & 9 & & 12 & 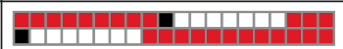 \\
\hline 11 & & 12 & 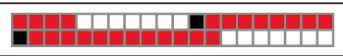 & 11 & & 10 & \begin{tabular}{|l|l|} 
\\
\end{tabular} \\
\hline 13 & & 14 & 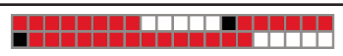 & 13 & & 8 & 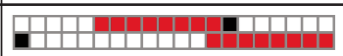 \\
\hline 17 & & 18 & 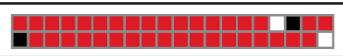 & 17 & & 4 & 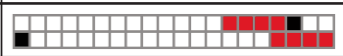 \\
\hline
\end{tabular}

ly covered effect is generated. $W_{11}$ is shifted to the left side under the gathering effect of the weft floats of $Y_{1}$, and the red weft point on $R_{2}$ can be covered by both $Y_{1}$ and $Y_{2}$. Based upon the interaction of all of these factors, the red weft point can be totally covered (figure 13). The longer the overlapping length of the yellow weft floats, the better the coverage effect. Based on the above analysis, the location of the critical position determines the number of partly covered effects and totally covered effects; which is in turn determined by the increasing number of interlacing points at the overlapping adjacent weft yarns of PW-C. In the case in which the repeat weave and the starting point of PW-C are fixed, the three effects can be freely controlled by regulating the step number and the transition direction of PW-C. For a 20-thread sateen weave, six effective step numbers may occur in the weft direction, namely, 3, 7, 9, 11, 13 and 17. As shown in table 2, when the transition direction of $\mathrm{PW}-\mathrm{C}$ is right, to reach a totally covered effect, the increasing number of interlacing points is $4,8,10,12$, 14 and 18; therefore, the larger the step number of PW-C, the smaller the totally covered effect and the greater the partly covered effect. When the transition direction of PW-C is left, the increasing number of interlacing points is $18,14,12,10,8$ and 4 ; thus, the larger the step number of $\mathrm{PW}-\mathrm{C}$, the greater the totally covered effect and the less the partly covered effect. In the process of fabric design, the step number and the transition direction of PW-C can be flexibly selected according to the design effect, which in turn affects the parameters of PW-A and PW-B.

\section{Analysis of the colour rendering law}

The specimens at the edge of the colour card (on the lines of $A B, B C, A C, A^{\prime} B^{\prime}, B^{\prime} C^{\prime}$ and $A^{\prime} C^{\prime}$ ) were measured two times using $X$-rite Colour i7 under a temperature of approximately $25^{\circ} \mathrm{C}$, a humidity of $65 \%$ and the following settings [17-20]: D65, $17 \mathrm{~mm}$ aperture, and $\mathrm{CIE} 10^{\circ}$ supplementary standard observer to collect the colour values $\left(L^{*}, a^{*}, b^{*}, C\right)$. Uniform and smooth transition of the SWDs is necessary for studying the colour shading effect of woven fabrics with the compound full-backed structure. The colour shading effect of the compound structures is analysed in terms of the colour values.
As shown in figure 14, for the face side of the colour card, the $L^{*}$ value of $A B$ with unchanged surface weaves was relatively stable, and that of $B C$ with two sets of SWDs (SWD-A and SWD-B) and AC with three sets of SWDs (SWD-A, SWD-B and SWD-C) showed a steady upward trend, demonstrating that the $L^{*}$ values on the face side of the specimens are consistent with visual observation. For the reverse side of the colour card, the $L^{*}$ values of $A^{\prime} B$ ' with a set of SWD (SWD-C) increased slightly because the $L^{*}$ of the warp yarn (90.20) is very close to that of the yellow weft yarn (83.30), so the $L^{*}$ values of $A^{\prime} B^{\prime}$ do not change significantly along with the shading process, but the overall trend is consistent with the visual observation. The $L^{*}$ values of $B^{\prime} C^{\prime}$ with unchanged weaves had a balanced downward trend, and that of $A^{\prime} C^{\prime}$ with three sets of SWDs steadily declined first and then increased gradually. Considering that the colour effects on the reverse side of the colour card are slightly complicated, the analysis of their $L^{*}$ values cannot accurately reflect the shading effect in detail; thus, colour purity and colour difference were further studied.

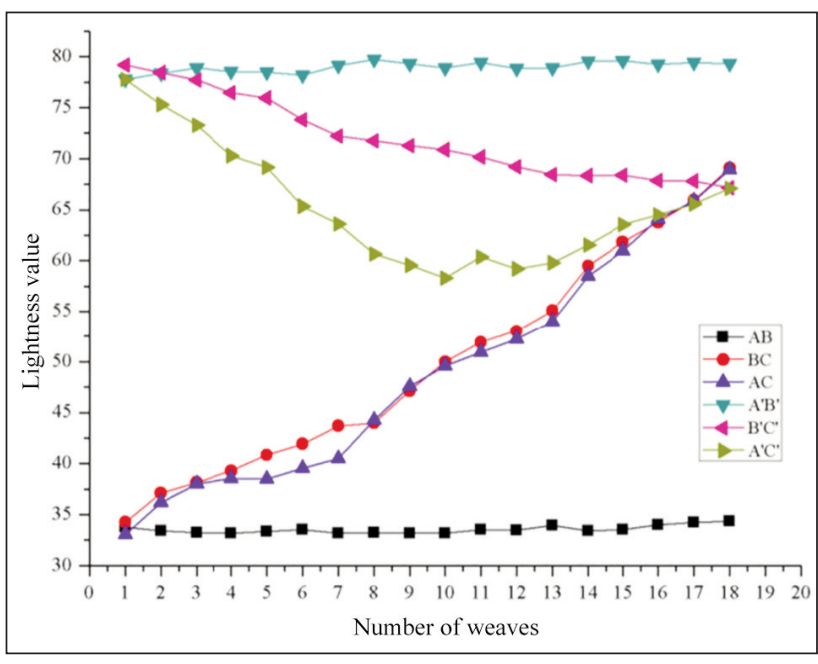

Fig. 14. $L^{*}$ values of the fabric specimens

The length of the weft floats along with the shading weaves causes the change in the colour purity. In figure 15 , the $R^{2}$ of $A B$ was 0.078 , which is close to 0 , indicating that the fitted line was nearly parallel to the 

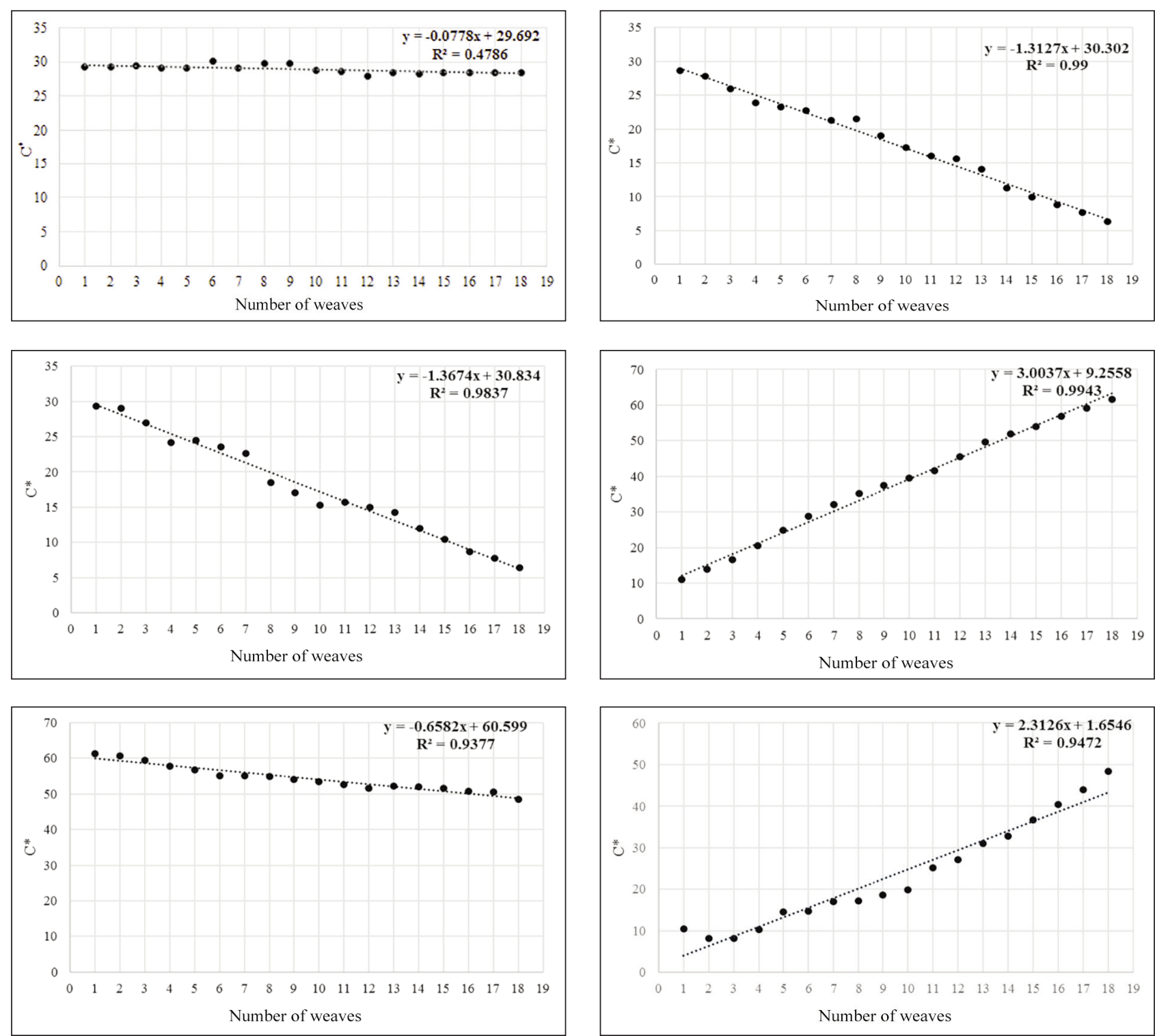

Fig. 15. Colour purity of the specimens

$X$-axis, so the colour purity was almost constant; the $R^{2}$ values of $B C, A C, A^{\prime} B^{\prime}, B^{\prime} C^{\prime}$ and $A^{\prime} C^{\prime}$ were 0.990 , $0.984,0.994,0.938,0.947$, respectively, all greater than 0.7 and close to 1 , showing good linearity and indicating that the colour purity exhibited a substantially uniform change.

The colour differences (equation 5) [18] of the specimens with three SWDs were calculated by comparing the colour values of two adjacent fabric specimens with each edge of the colour card:

$$
\Delta E_{a b}^{*}=\sqrt{\sum_{i=1}^{n}\left(\Delta L^{* 2}+\Delta a^{* 2}+\Delta b^{* 2}\right)}
$$

where $\Delta E_{a b}^{*}$ is the colour difference of the fabric specimens, $n$ - the number of specimens, and $\Delta L^{*}=L_{i}^{*}-$ $L_{i+1}^{*}, \Delta a^{*}=a_{i}^{*}-a_{i+1}^{*}$, and $\Delta b^{*}=b_{i}^{*}-b_{i+1}^{*}$.

In the evaluation of the colour mixing effect of the woven fabrics, $\Delta E_{a b}^{*}$ in the range of $2-5$ is generally supposed to indicate a trace or slight colour difference [21]. As illustrated in tables 3 and 4, the calculation results showed that the average colour differences of $A B, B C, A C, A^{\prime} B^{\prime}, B^{\prime} C^{\prime}$, and $A^{\prime} C^{\prime}$ are 2.54,
$3.15,3.32,3.03,1.23$ and 3.69 , respectively, all in the range of 2-5, indicating that the colour shading effect was adequate. In addition, the colour difference of the specimens with three sets of SWDs was the highest (3.32 of $A C$ and 3.69 of $A^{\prime} C^{\prime}$ ), followed by those with two sets and one set of SWD (3.15 of BC and 3.03 of $\left.A^{\prime} B^{\prime}\right)$, and that of the unchanged weaves (2.54 of $A B$ and 1.23 of $B^{\prime} C^{\prime}$ ) was the smallest.

\section{APPLICATION DESIGN}

With digital jacquard design technology under layered-combination design mode, a compound fullbacked structure can produce double-faced shading effect fabrics with three coloured wefts. For the face side of the fabric, there is one or two sets of weft colours shaded into warp colour, or into each other. For the reverse side of the same position of the fabric, along with the shading process of the rest set of wefts, three effects which are partly covered effect, totally covered effect and these two effects existing at the same time can be generated. For a compound full-backed structure, the effects on the face and 


\begin{tabular}{|c|c|c|c|c|c|c|c|c|c|}
\hline \multicolumn{10}{|c|}{$\begin{array}{l}\text { LIGHTNESS DIFFERENCES AND AVERAGE COLOUR DIFFERENCES ON THE FACE SIDE OF THE FABRIC } \\
\text { SPECIMENS }\end{array}$} \\
\hline \multirow{2}{*}{ Number } & \multicolumn{3}{|c|}{ AB } & \multicolumn{3}{|c|}{ BC } & \multicolumn{3}{|c|}{$A C$} \\
\hline & $\Delta \mathrm{L}^{*}$ & $\Delta a^{*}$ & $\Delta \mathbf{b}^{*}$ & $\Delta \mathrm{L}^{*}$ & $\Delta \mathrm{a}^{*}$ & $\Delta \mathbf{b}^{*}$ & $\Delta \mathrm{L}^{*}$ & $\Delta \mathrm{a}^{*}$ & $\Delta b^{*}$ \\
\hline 1 & 0.39 & 0.21 & 0.55 & -2.87 & -2.16 & -7.91 & -3.13 & -1.79 & -7.18 \\
\hline 2 & 0.15 & 0.34 & 0.88 & -1.03 & 2.53 & 2.14 & -1.81 & 1.96 & -0.9 \\
\hline 3 & 0.04 & 0.24 & -0.27 & -1.13 & 3.71 & 3.41 & -0.54 & 3.45 & 2.81 \\
\hline 4 & -0.17 & -0.93 & -1.86 & -1.57 & 0.72 & -0.06 & 0.06 & 0.61 & 2.79 \\
\hline 5 & -0.16 & -1.99 & -2.78 & -1.07 & 0.19 & -0.68 & -1.05 & 0.53 & -1.07 \\
\hline 6 & 0.35 & 1.82 & 2.47 & -1.77 & 1.62 & 0.01 & -0.96 & 1.43 & 1 \\
\hline 7 & -0.05 & -1.49 & -2.26 & -0.28 & 0.4 & 0.9 & -3.75 & 3.33 & -2.78 \\
\hline 8 & 0.06 & 0.09 & -0.04 & -3.16 & 1.93 & -1.52 & -3.31 & 1.27 & -0.95 \\
\hline 9 & -0.01 & 1.93 & 2.69 & -2.84 & 1.33 & -1.11 & -2.04 & 1.54 & -0.7 \\
\hline 10 & -0.36 & 0.39 & 0.5 & -1.94 & 0.88 & -0.93 & -1.34 & 0.01 & 1.01 \\
\hline 11 & 0.08 & 1.61 & 1.5 & -1.12 & 0.46 & -0.04 & -1.32 & 0.68 & -0.12 \\
\hline 12 & -0.51 & -1.05 & -0.95 & -2.05 & 1.13 & -1.29 & -1.75 & 0.56 & -0.63 \\
\hline 13 & 0.54 & 4.41 & 6.5 & -4.4 & 2.36 & -1.47 & -4.45 & 2.22 & -0.61 \\
\hline 14 & -0.08 & -1.93 & -2.35 & -2.36 & 1.54 & 0.04 & -2.53 & 1.82 & 0.39 \\
\hline 15 & -0.47 & 1.29 & 1.8 & -1.92 & 1.29 & -0.18 & -3.12 & 1.57 & -0.82 \\
\hline 16 & -0.27 & -3.93 & -6.06 & -2.17 & 1.2 & -0.24 & -1.76 & 1.35 & 0.34 \\
\hline 17 & -0.11 & 0.75 & 1.46 & -3.15 & 1.48 & -0.39 & -3.05 & 1.9 & 0.21 \\
\hline AVG of $\Delta E_{a b}^{*}$ & \multicolumn{3}{|c|}{2.54} & \multicolumn{3}{|c|}{3.15} & \multicolumn{3}{|c|}{3.32} \\
\hline
\end{tabular}

\begin{tabular}{|c|c|c|c|c|c|c|c|c|c|}
\hline LIGHTNESS & $\mathrm{NC}$ & VD A & $\begin{array}{l}\text { GE } \\
\text { FAB }\end{array}$ & $\begin{array}{l}\text { DUR } \\
\text { SPE }\end{array}$ & $\begin{array}{l}\text { ERE } \\
\text { NS }\end{array}$ & ON & $\mathrm{F}$ & 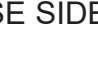 & Tr \\
\hline \multirow{2}{*}{ Number } & \multicolumn{3}{|c|}{$A^{\prime} B^{\prime}$} & \multicolumn{3}{|c|}{$B^{\prime} C^{\prime}$} & \multicolumn{3}{|c|}{$A^{\prime} C^{\prime}$} \\
\hline & $\Delta \mathrm{L}^{*}$ & $\Delta \mathrm{a}^{*}$ & $\Delta \mathbf{b}^{*}$ & $\Delta \mathrm{L}^{*}$ & $\Delta \mathrm{a}^{*}$ & $\Delta \mathbf{b}^{*}$ & $\Delta \mathrm{L}^{*}$ & $\Delta \mathrm{a}^{*}$ & $\Delta \mathbf{b}^{*}$ \\
\hline 1 & -0.55 & 0.7 & -2.85 & 0.74 & -0.01 & 0.77 & 2.46 & -0.2 & 2.22 \\
\hline 2 & -0.54 & 0.63 & -2.79 & 0.73 & -0.51 & 1 & 2.03 & -1.09 & 0.06 \\
\hline 3 & 0.36 & 1.03 & -3.68 & 1.22 & -0.33 & 1.65 & 2.99 & -1.13 & -2.09 \\
\hline 4 & 0.02 & 0.72 & -4.25 & 0.53 & -0.4 & 1.07 & 1.15 & -0.14 & -4.17 \\
\hline 5 & 0.31 & 0.75 & -4.04 & 2.16 & -0.49 & 1.61 & 3.8 & -0.37 & -0.22 \\
\hline 6 & -0.94 & 0.61 & -3.05 & 1.58 & -0.78 & -0.22 & 1.72 & -1.15 & -2.04 \\
\hline 7 & -0.56 & 0.98 & -3.03 & 0.48 & -0.49 & 0.31 & 2.99 & -2.85 & 0.65 \\
\hline 8 & 0.37 & 0.38 & -2.2 & 0.47 & -0.29 & 0.83 & 1.07 & -0.41 & -1.46 \\
\hline 9 & 0.42 & 0.21 & -2.21 & 0.38 & -0.17 & 0.52 & 1.29 & -0.48 & -1.14 \\
\hline 10 & -0.51 & 0.22 & -2.06 & 0.71 & -0.72 & 0.84 & -2.07 & 0.51 & -5.6 \\
\hline 11 & 0.61 & 0.28 & -3.87 & 0.95 & -1.45 & 0.81 & 1.13 & -1.19 & -1.79 \\
\hline 12 & -0.11 & 0.36 & -4.17 & 0.77 & -0.56 & -0.53 & -0.58 & 1.63 & -4.43 \\
\hline 13 & -0.63 & -0.13 & -2.32 & 0.1 & 0.08 & 0.05 & -1.73 & 2.73 & -2.24 \\
\hline 14 & -0.03 & 0.45 & -1.97 & -0.02 & -0.29 & 0.37 & -2.02 & 1.44 & -3.9 \\
\hline 15 & 0.35 & 0.21 & -2.85 & 0.53 & -0.69 & 0.88 & -0.95 & 0.58 & -3.7 \\
\hline 16 & -0.19 & 0.37 & -2.31 & 0.03 & -0.41 & 0.3 & -1.08 & 0.77 & -3.69 \\
\hline 17 & 0.14 & 0.27 & -2.34 & 0.66 & -0.16 & 1.87 & -1.49 & 1.48 & -4.35 \\
\hline AVG of $\Delta E_{a b}^{*}$ & \multicolumn{3}{|c|}{3.03} & \multicolumn{3}{|c|}{1.23} & \multicolumn{3}{|c|}{3.69} \\
\hline
\end{tabular}




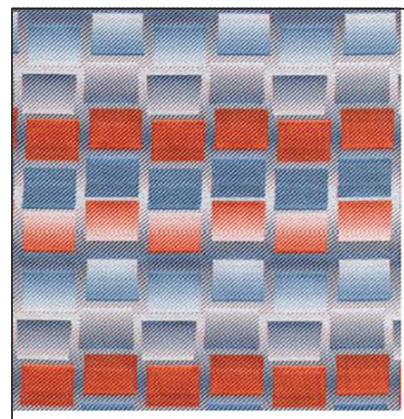

Face side

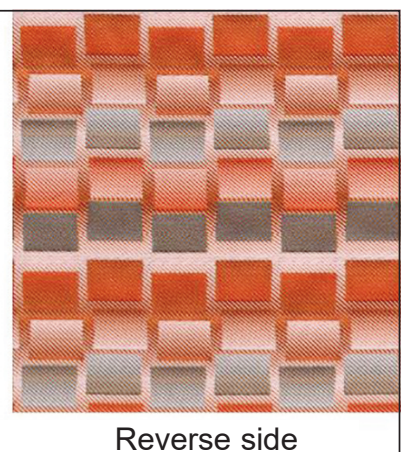

Reverse side
Fig. 16. Double-faced jacquard fabric with a compound full-backed structure with three wefts

reverse sides can also be reversed on the jacquard fabrics based on the structure features. What calls for special attention in the design process is that the float length of the surface weaves should always be longer than that of the backing weaves. With this structure, double-faced fabrics can be mass produced and have no limitation on the subject of design patterns.

\section{CONCLUSIONS}

The traditional jacquard design method has great limitations in structural design when designing doublefaced weft-backed fabric with three sets of wefts. A compound full-backed structure based on the weftbacked structure with compound weft colour effects is employed for its possibility of creating double-faced weft-backed fabric. The main features of the combination of the non-backed effect on one side and fullbacked effect on the other side with the composition of the three SWDs are applied when designing a double-faced fabric with three wefts. By reasonably configuring of the PWs and designing compound fullbacked technical points, colour shading effects are generated in which two sets of wefts produce shading effect on one side totally covering the remaining set of weft yarns that are producing shading effect on the other side of the fabric. In addition, the experimental results show that a uniform colour shading effect can be realized with three SWDs, and the covering effect on the reverse side of the jacquard fabric can be controlled by changing the parameters (the step number and the transition direction) of the PWs. The design method described in this study further perfects the digitization of the weft-backed structure and provides a reference for the innovation of structural design and colour design of double-faced weftbacked fabrics.

\section{ACKNOWLEDGEMENTS}

Authors are thankful for providing the funds by the 2018 "the Light of Textile" Foundational Applied Research Project, grant no. J201802, Key Laboratory Project of the Ministry of Culture of China (2017016) and the Academic Dissertation Foundation's Project of Priority Discipline Master Degree of Zhejiang Province of "Textile Science and Engineering", grant no. 11110832271601.

\section{REFERENCES}

[1] Han, R., Zhang, S., Design and production of the digital double-faced jacquard fabric with different photographic patterns on face and back, In: Journal of Textile Research, 2006, 27, 8, 89-91

[2] Pelin, G.U., Gonca, O.K., Zehra, E.K., The Effect of Different Connections in Double Layered Woven Fabrics on Comfort Properties, In: Fibers and Polymers, 2012, 13, 2, 258-263

[3] Jin, Z., Xu, J., Double Face with Pattern Effect Design of Thermal Jacquard Based on Three-Layer Weave Structure, In: Applied Mechanics and Materials, 2014, 442-446

[4] Zhejiang Institute of Silk and Textiles, Suzhou Institute of Silk and Textiles, Weave and Structure of Woven Fabric: volume two, In: Textile Industry Press, Beijing, 1997

[5] Luo, B., Structure design of weft decorative fabric, In: Shanghai Textile Science \& Technology, 2003, 31, 3, 59-62

[6] Zhang, A., Wang, X., Design and Research of the Foldable Decorative Screen with Ethnic Style Based on WeftBacked Structure, In: Advanced Materials Research, 2011, 331, 69-72

[7] Kim, K.R., Ng, F., Zhou, J., Hu, J., Diamond-shaped shaded weave series created by transforming small twills to enrich the surface texture of woven Jacquards, In: Textile Research Journal, 2016, 86, 10, 1032-1040

[8] Zhang, A., Zhou, J., Colour rendering in single-layer jacquard fabrics using sateen shaded weave databases based on three transition directions, In: Textile Research Journal, 2018, 88, 11, 1290-1298

[9] Kim, K.R., Ng, F., Zhou, J., Hu, J., Gradient colour deviation in woven textiles to correspond to pictorial images in diversity, In: International Journal of Fashion Design, Technology and Education, 2016, 9, 1, 32-40

[10] Zeng, D., Cooperation of banister harness and stitch weave, In: Jiangsu Silk, 1986, 4, 39-44

[11] Ma, X., Luo, B., Decorative fabric design based on analysis of traditional brocade, In: Shandong Textile Scie., 2016, 2, 15-18

[12] Ng, F., Zhou, J., Full-colour compound structure for digital jacquard fabric design, In: The Journal of the Textile Institute, 2010, 101, 1, 52-57

[13] Zhou, J., Hu, D., Design of superimposition-effect digital jacquard fabric based on layered-combination design mode, In: Journal of Textile Research, 2013, 34, 41-44

[14] Zhou, J., Bai, L., Design research and practice on gradient weft-full-backed structure, In: Journal of Textile Research, 2018, 39, 1, 34-39 
[15] Zhou, J., Zhang, M., Design principle and method of combined jacquard half-backed structure, In: Journal of Textile Research, 2017, 38, 6, 40-45

[16] Ng, F., Zhou, J., Innovative layered-combination mode for digital jacquard fabric design, In: Textile Research Journal, 2009, 79, 8, 737-743

[17] Keiji, O., Reproduction of various colors on Jacquard textiles by only eight kinds of color wefts, In: 9th Congress of the International Colour Association, Proceedings of SPIE, 2002, 442102

[18] Mathur, K.A., Donaldson, D., Hinks, A.M.S., Color on Demand for Jacquard Fabrics, In: Research Journal of Textile and Apparel, 2005, 9, 4, 26-37

[19] Dimitrovski, K., Gabrijelčič, H., Influence of size and distribution of colour components on colour values of woven fabric, In: 5th International Conference TEXSCI 2003, Czech Republic, 2003, 305-312

[20] Harpa, R., Visileanu, E., From fabric design to the dress manufacturing considering the fabric's suitability with the end use, In: Industria Textila, 2018, 69, 6, 434-439, http://doi.org/10.35530/IT.069.06.1570

[21] Robertson, A.R., The CIE 1976 colour-difference formula, In: Colour Research and Application, 1977, 2, 7-11

\section{Authors:}

LINLIN BAI ${ }^{1}$, JIU ZHOU ${ }^{2}$

${ }^{1}$ Shaoxing University, Key Laboratory of Clean Dyeing and Finishing Technology of Zhejiang Province, Huancheng West Road No. 508, 312000, Shaoxing, Zhejiang, China

e-mail: bailinlin0210@163.com

${ }^{2}$ Zhejiang Sci-tech University, Silk and Fashion Culture Research Center of Zhejiang Province,

Xiasha Higher Education Zone No. 928, 310018, Hangzhou, Zhejiang, China

\section{Corresponding author:}

JIU ZHOU

e-mail: zhoujiu18515@126.com 